\title{
TOWARD CONTEMPORARY ART EDUCATION: SOME ACTUAL TOPICS, DISCUSSED BY TEACHER TRAINING PROGRAMME AT THE UNIVERSITY OF MARIBOR
}

\author{
Tomaž Zupančič, PhD, assistant prof. \\ Faculty of Education \\ University of Maribor (Slovenia) \\ e-mail: tomaz.zupancic@uni-mb.si
}

\section{S u m m ary}

The article presents some contemporary art educational tasks, incorporated into the teacher training programme at the University of Maribor. These tasks arise from basic post-modern orientation of contemporary art education. One of the most significant tasks of contemporary art education in the post-modern era is to train a young person to understand the culture she or he is living in. Contemporary art education has global foundations. In accordance with the post-modern manner it emphasises concepts. It pulls down barriers between high and popular art. It is intercultural and multicultural and it deals with the aspect of culture of peace.

If development of creative potential, training for visual literacy and understanding of contemporary cultural world remain constants of art education, then two things should be added in accordance with the modern time: (1) development of ecological awareness and (2) care for human rights, especially in the sense of emphasizing tolerance and equality.

Efforts to promote the spirit of understanding, peace, tolerance, gender equality and friendship among all nations, nationalities and religions are the basic civilization obligation of a contemporary society and an essential task of education as well.

Key words: Art education, post-modernism, contemporary art, ecology, peace, tolerance

\section{Introduction}

Contemporary objectives of art education derive from art education concepts adopted at the Paris InSEA congress back in 1976. Next to their responsibility to develop, enrich and foster students' artistic abilities and creativity, the main task of art teachers, according to Berce-Golob, is to use their own creativity to teach pupils how to experience beauty in nature and works of art, as well as how to appreciate artworks, handy objects, and art-related issues in a certain setting. Thus, pupils get accustomed to easier understanding of other media that are part of the visual culture (Berce-Golob, 1982, p. 10). The author further notes that a developed feeling of love towards artistic creations as well as a sense of understanding of the social and humanistic role of art, past and present, are considered to represent the highest level of a student's attitude towards culture and art (Berce-Golob, 1982). Art education in our country (in Slovenia and back then in Yugoslavia) also has been committed to 
these goals which are comparable to global views regarding this particular discipline. After the 1980 reform of art education and thereafter, art education was additionally enriched and intertwined with other fields. As Berce-Golob writes, in addition to problem based approach, equal representation of art forms, as well as modern teaching methods and forms, contemporary art education practices give room for interconnections with other fields of art as well as enable and require integration with a wider environment (Berce-Golob, 1993: pp 13-14).

Over the past twenty years $(1990-2010)$ further steps have been made in art education. The goals as well as views of this academic area have been expanded and the positions with regard to it have changed as well. The changes applied to contemporary art education practice derive from research in the respective discipline, though they are partially influenced also by contemporary findings in pedagogy and didactics in general, by cultural studies, by the development of visual art (postmodernism theories and alike), and lately also and in particular by the introduction of a sustainable development paradigm and the emergence of new media.

\section{Directions of contemporary art education}

In his reflections on postmodern curriculum in the early nineties of the twentieth century, Arthur Efland posed two key questions regarding art education, namely, what is the purpose of art and hence, what is the purpose of art education in a postmodern era? He realised that "the function of the arts continues to be "reality construction." And hence we teach art to widen and deepen our understanding of the cultural landscape we inhabit." (Efland, 1992, p. 118). According to Hickman, this is the way for individuals to socialise and play their role in the social landscape they come from (Hickman, 2005b, p. 52). Thus, art subjects at different levels of school education have gained an extra broadness which displays itself through the content as well as through the procedures used (didactics).

The directions of contemporary art education over the past twenty years could be summarised by the following: Contemporary art education practice is based on global foundations which underline the globalisation of human rights; justice, equality, independence and freedom for each individual (Said, 1991; quoting: Jagodzinski 1999, p. 316). This means that art lessons regardless of the level of schooling should discuss topics that emanate a positive attitude towards respect for human rights, and that artistic communication in class is about discussing different viewpoints, considering one another, developing a sense of empathy and similar. In accordance with the postmodern voice, contemporary art education highlights the concepts, ideas and connections between an artwork on the one hand, and social, cultural and political issues on the other (Dawtrey 1996; Hardy 2006; Hickman 2005a). In other words, work at school is intertwined with conceptual art works of the past fifty years; students learn about cultural as well as political backgrounds behind individual works of art; and the activities are planned according to the current social action. Students have to see the sense in art as well as in their own artistic expression. Contemporary art education practice transcends the modernist 
adherence to formal qualities of an artwork, breaking down the barriers between "high" and "popular" art (Boughton 1999). In art classes, students are introduced to present and past artworks all the while paying equal attention to the emergence of popular culture, comic strip, animated movie, popular music and alike. The value judgements are left in the hands of each individual. Art education today is intercultural or multicultural for that matter (Boughton and Mason 1999; Hernández 1999). This implies that cultural facilities of different cultures, nations, as well as sub-cultural and marginal groups who frequently live on the edge of society are discussed and showcased in art classes, hence enabling cultural intertwining and mutual nourishment. Furthermore, contemporary art education strives to transcend western art canons (Jagodzinski 1999) in addition to unique and "right" decoding of art works and their interpretation, but also goes beyond praising of individual authorship. A teacher complies with the Method of Conceptual Art Education (Zupančič, 2006, pp. 29-39), which means they do not give a final critical verdict on works of art but rather let students develop their own viewpoints. Contemporary art education deals with various aspects of the culture of peace (Wintersteiner 2003; Mason 1999). In other words, the teacher showcases cultural facilities and artworks that concern or criticise violence, highlights ethical commitment of visual arts and the need of coexistence on the nowadays globalised planet, which is marked by quality and tolerance. And last but not least, contemporary art education underlines through its contents the development of ecological conscience and education towards a sustainable development. An increasing share of people within the profession of pedagogy is aware of the fact that sustainable development is turning progressively into a global paradigm which contemporary art education is subject to. In the past five years, the so-called sustainable paradigm has become one of the crucial segments of contemporary art education. A recent conference of the International Society for Education through Art (InSEA), which took place in Rovaniemi, Finland, in 2010 was entirely dedicated to different aspects of sustainable art education (http://www.ulapland.fi/InEnglish/Units/Faculty_of_Art_ and_Design/About_the_Faculty/Events/InSEA.iw3).

\section{Care for human rights with the emphasis on respect for tolerance and equality}

The issue of human rights is present in all segments of contemporary art education, with particular attention being paid to religious differences. To illustrate how the respective issue is dealt with is a dilemma which is being discussed with students as part of a series of lectures titled Criteria for Assessment of Students' Artwork. During these lectures we open a topical question: How should teachers react when they come across a student's artwork that incorporates criticism of a religious theme? How then to react in case someone in class produces something similar to the controversial Muhammad cartoons published on September 30, 2005 in the Danish newspaper Jyllands Posten, thus insulting religious feelings of one of their classmates? 
The discussion with students incites possible strategies. Normally, we come to the conclusion that the teacher in fact has three alternatives. Firstly, they can protect the wounded feelings of the religious classmate by forbidding any artistic communication that might be insulting. Secondly, they may align themselves with the author of the respective artwork. This speaks in favour of the three-dimensional toleration of which Waldron says the following: "Persons and peoples must leave one another free to address the deep questions of religion and philosophy the best way they can, with all the resources they have at their disposal. In the modern world, that may mean that the whole kaleidoscope of literary technique - fantasy, irony, poetry, word-play, and the speculative juggling of ideas - is unleashed on what many regard as the holy, the good, the immaculate, and the indubitable" (Waldron, 1998, p. 148). Hence not only ideas but also the ways one delivers ideas differ. What someone finds humorous or funny and thus a legitimate method of delivering their idea might be insulting and inappropriate for someone else. Considering that the number of lessons dedicated to art is limited, this makes our problem unsolvable.

The third option, however, is for the teacher to choose probably the best and the only appropriate way. Instead of assuming the role of an arbiter, the teacher uses the conflict to discuss the issue in question. As there is no simple solution to the problem, neither in school nor within the society in general (and there is a number of real examples that might account for this), it is the more important that such an issue is discussed in class. Students must become aware of the fact that there will be certain problems that from different perspectives not only appear but in fact are different. Instead of trying to find a definite solution which is impossible in many cases, we should teach our students of the differences in the modern world. These are not exclusive but rather help develop our skills of coexistence which is indispensable and enriching at the same time.

Another important question students are confronted within one series of lectures is: Which are the forbidden topics that a teacher cannot tolerate? And are we at all qualified to not allow certain topics in school?

In this particular discussion we lean on the point made by Slavoj Žižek regarding the so-called unutterable topics. The discussion by Žižek refers to political discourse in a modern, democratic society, yet can easily be translated to education. Žižek unveils his idea by means of a comparison between a politician who openly refers approvingly to e.g. Fascism and one that does not reveal his approval openly but hides it instead. Žižek opposes the idea that it is better to have something to do to with the one that publicly presents his ideas because at least so we know where we are at, contrary to someone who speaks one thing and thinks another (Žižek, 1997a, p. 71). He thus argues that it is not "better for us to deal with the enemy who openly admits his (racist, homophobic ...) bias than with the hypocritical attitude of publicly denouncing what one secretly and actually endorses" (Zižek, 1997b, p. 26). The reason for this is simple. At a certain level of civilisation, culture, and democracy in a society, certain topics and statements are a taboo, unutterable, blaspheme and removed from the public vocabulary without the possibility of an appeal. The latter is apparent in a setting that nourishes a high level of political culture and slightly less obvious in others. Some settings punish intolerant behaviour 
immediately (and send politicians to the history dump), while elsewhere, intolerant statements are unfortunately still part of the political discourse.

The situation in schools today is pretty much the same. Modern school derives from human rights and the 'rule of law' notion (Krek, 1995, p. 13), while its directions are based on the Universal Declaration of Human Rights. Article 26 of the latter reads: "Education shall be directed to the full development of the human personality and to the strengthening of respect for human rights and fundamental freedoms. It shall promote understanding, tolerance and friendship among all nations, racial or religious groups, and shall further the activities of the United Nations for the maintenance of peace" (Krek, 1995, p. 15).

In line with the above, school is a field that leaves no room for certain topics, expressions, ideas. These undoubtedly include any racist, homophobic or xenophobic ideas, religious prejudice and stereotypes, display of sadistic behaviour towards living beings and alike. As regards the issue of setting the boundaries between still admissible and inadmissible statements, which depends also on the set of values of each individual, teachers should be extensively autonomous, being mature, professionally trained, and responsible individuals that are conscious of their responsibilities as well as of the basic directions of modern school.

\section{Problem}

The development of the line of thought regarding contemporary art education at the University of Maribor takes place at two levels. In practice, it is projected as a basic conceptual principle in the lectures within the course titled Visual Art Didactics which is part of the Art Pedagogy university programme. On the theoretical level, however, we have been developing, as part of our scientific research activities, a didactic model for teaching contemporary visual art, which we have called the Method of Conceptual Art Education (Zupančič, 2006, 2007).

As it is our wish to combine the two segments, that is, the scientific thought and the educational practice at university, we have planned a research study. The main objective of the latter was to establish whether the directions of contemporary art education received positive response with students and why. The research study questions were set so as to show which of the current topics discussed within the course were regarded as interesting, which were considered to be the most important for the students' future work as teachers, which of them the students found redundant and unnecessary, but also what were students' views with regard to each of the directions of contemporary art education practice.

Our research questions referred to individual series of lectures (i.e. thematic clusters), which incorporate all of the above mentioned directions of art education. These principles are incorporated across thematic clusters. For example, in the series of lectures titled Contemporary Art Education Theories we discuss the problem of transcending individual authorship in modern art, while as part of the series of lectures Psychological Features of Early Adolescence we discuss thinking beyond the distinction between high and popular art, and so on. The direction of contemporary art education which we named Transcending Formal Visual Art 
Paradigm in Contemporary Art is treated within a separate thematic cluster, though it is also present across other clusters as well. A concrete example of studying one research segment was presented earlier in the section Care for Human Rights with the Emphasis on Respect for Tolerance and Equality.

\section{Sample}

Included in the research sample were students who attended the fourth year of Art Pedagogy at the Faculty of Education, University of Maribor, in the school year 2010/2011. Subjects were all 26 students (male and female) in the respective class. They were asked to fill in our questionnaire after each of the 19 series of lectures. On average, 10.1 respondents completed the questionnaire for each thematic cluster.

\section{Method}

We have used a qualitative method of pedagogical research. After each series of lectures (thematic clusters) in the Visual Art Didactics II course (60 lessons, 19 thematic clusters) the students were asked to fill in questionnaires which were anonymous and voluntary. Each time, they were given 10 minutes immediately after the lecture to complete the questionnaires. The respondents had to assess the content of the completed series of lectures using Likert-type 10-point scale $(0-$ the least interesting; 10 - the most interesting). Furthermore, they ranked each thematic cluster according to how useful they thought it would be in practice by means of a closed-type question. The possible answers were as follows: A) More useful than others; B) Equally useful; C) Less useful; and D) Other. In addition, the questionnaire included two open-type questions in which students were to quote on the one hand the most interesting and the most useful things (with regard to the content as well as the ideas) in the series of lectures completed and on the other hand, the least interesting and the least useful i.e. unnecessary.

In the Likert-type questions as well as the closed-type questions we have computed the mean values which we presented as absolute and percentage frequencies. In open-type questions, however, we merged the responses according to their meaning and subsequently interpreted them. We have in all processed 193 questionnaires which we collected between October 2010 and April 2011.

\section{Results and discussion}

We used a 10-point scale to establish how interesting the topics were. On average, the students did find the contemporary topics interesting. The lowest average score for a series of lectures was 8 and the highest was 9.66. The overall average score for all 19 clusters was 8.79 , the mode was 10 and the median 9 .

As regards usefulness of each thematic cluster, the respondents generally claimed that each cluster was equally useful as others (51.29\%), while $17.61 \%$ of the respondents found individual clusters more useful than others and only $11.91 \%$ of the respondents thought a specific cluster was less useful in practice compared to 
others. The remaining respondents have chosen the response 'Other', noting that they were unable to make such a comparison. This has mostly occurred after the first couple of lecture series where it was indeed impossible to compare one to another, and (partly) when respondents did not attend the lectures regularly.

As regards specific directions and thematic clusters, the open-type questions have led to the following conclusions:

(1) Training young people to understand the culture they inhabit is one direction that was frequently listed by the students. What they found particularly useful was Efland's comparison between school subjects in science and art. He argues that the main reason behind teaching science subjects (mathematics, physic, biology etc.; note by the Author) is to train young people to understand the natural landscape which they inhabit. On the contrary, art subjects enable young people to understand the social and the cultural setting around them (Efland, 1992, p. 120)

The relations are presented as a scheme in the image below.

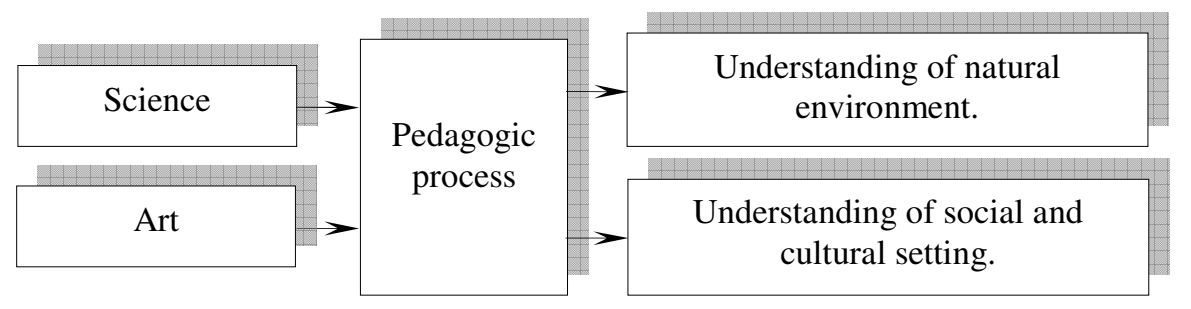

Image 1. Basic goal of teaching school subjects in science and art

The emphasis of education in light of understanding contemporary culture was present in almost all of the thematic clusters. Even when this was not the central topic, students' responses still did include some views regarding this aspect. A characteristic view of the respondents is illustrated with the following statement:

»To me, the most useful thing was to learn how to familiarise students with contemporary teaching methods, and how to find the sense of art education ourselves.« (Statement of respondent A)

(2) Integration of art education topics with everyday life and interests of the students was the next direction most frequently mentioned in the questionnaire. The respondents i.e. students on many occasions perceived art education topics as estranged from the interests of pupils/students and were highly motivated to look for strategies on how to bring the topics closer to them. Some typical statements of students were:

»In practice I shall use additional illustrations such as reading from newspapers or finding correlation between art content and recent events. This is what they are curious about.« (Statement of respondent E)

»I will use the facts regarding the student dance parade; this has opened an entirely new perspective to me.« (Statement of respondent G) 
»The comparison of the importance of Wikipedia against a standard encyclopaedia was extremely useful. I will use it to motivate pupils. « (Statement of respondent $\mathrm{K}$ )

There were eight answers with similar meanings as the last one in the section addressing this issue.

(3) Highlighting concepts was another thing that students tended to point out. There are two aspects to this issue, namely, showcasing examples of conceptual art as part of art classes, and highlighting concepts in practice i.e. in pupils' or students' art-making. Since practical work of art students in their fourth year is almost entirely conceptual, students were the more in favour of this particular aspect. Some typical statements were:

"What I find valuable is the thought on how to simply explain to the pupils what conceptual art is about. And of course underlining the fact that conceptual art needs to be present in class. « (Statement of respondent D)

»It is interesting that we discuss contemporary problems and current topics. The work in art classes should derive from a concept with which students first express what they want to say.« (Statement of respondent F)

»Thinking out of the box.«(Statement of respondent $\mathrm{H})$.

(4) Breaking the barriers between high and popular art emerged in various clusters. We underlined it while discussing strip cartoon art, graffiti and alike. Students tended to relate this aspect to the integration of art education topics with everyday life and interests of the students. Pupils/students follow and absorb popular culture so the latter might feature as a bridge between them and the course content. Furthermore, they underlined the correlation between art content and popular music (rap, punk, rock, pop, etc.).

»Emphasizing that comic strips do have artistic value and encouraging us to correlate art content with popular music. This is definitely something pupils like listening to.« (Statement of respondent I).

(5) Developing aspects of peaceful and non-violent culture was the next direction that students perceived as important and valuable in light of their future teaching practice. The aspects of a peaceful, non-violent, and ethic stand were emphasized in the discussion of visual art practices that consciously depict violence. This crucial issue was addressed in a separate research study as well (Cf.: Zupančič, 2011). Studying an identical sample, we discovered that while students were generally critical towards images of violence, death or mutilation in artworks, their opinions were still elaborate and objective. The respective research has shown, similar as this one, that students made a clear distinction between knowing how and when violence in art was justifiable, and accepting the fact that there were certain limitations within art education. One of the respondents has stated:

»I understand that by including violent imagery in their work, an artist may be protesting against violence, but I am also aware that I would not showcase this example in school as my pupils are not mature enough to understand this.« (Statement of respondent E) 
The content included different aspects of peaceful and non-violent culture. In one case we also addressed the question regarding which forms of violence an artist may use in their work. The respondents were unanimous in their thinking, which is best illustrated by the following statement:

$\gg$ An artist is responsible for all lives and cannot subject no one to death and pain, but himself or herself.« (Statement of respondent C)

(6) Development of an ecological conscience was the next aspect which the respondents saw as necessary and useful, although to a lesser extent than we had anticipated. They generally noted that environmental concerns were a serious issue in today's society, however, they did not agree in principle that the so-called sustainable paradigm should become the prevalent direction of contemporary art education. Their opinions in this regard referred in some cases to marginal occurrences, for example:

»Making comparisons and answering questions on environmental issues today, in particular us having to provide answers, thus exposing ourselves - this is what some professors tend to forget; they do not challenge students to think for themselves. «(Statement of respondent $\mathbf{J}$ )

Considering the anticipated outcome of the research study, we can say that sustainable paradigm is one of the directions, which surely needs more attention paid to in the future.

(7) Care for human rights with respect for tolerance and equality was the last on the list. This particular section turned out to be one of the most interesting ones as it received the highest average score (9.66). During the presentation already students were engaged in an exciting debate. In six cases, students thought that fostering tolerance, acceptance and the acceptance of differences were the most useful directions in practice, in two cases these were considered equally important as others, while only one respondent noted he or she could not make that judgement. In general, students are well aware that pupils/students differ with regard to their religious beliefs, cultural settings they inhabit, views and opinions. Also, they realise that this particular issue is complex with no unambiguous solution, and that they need a lot of information on how to deal with it in class. Two representative statements were:

»I found very useful the discussion between us on how to react in class when a person is hurt because of religious reasons or others - obesity etc. (Statement of respondent $\mathrm{B}$ )

»It depends on each case separately, yet I need to make sure than no one is hurt.« (Statement of respondent A)

»Today, there is a wide variety of students in each class and this is why I find this very interesting. « (Statement of respondent I)

\section{Conclusion}

Noemi Smolik (1999) asks herself which criteria may be used to judge contemporary art and responds: none. She further claims that there no longer exist 
universal rules on the definition of art. After 1917 when Duchamp created his Fountain, art remains purely as a category to be agreed upon. According to Smolik, what we recognise as a work of art depends much more on an agreement within a certain group (Smolik 1999, pp. 95-96). All that matters is the response, the change triggered by something else, Smolik notes, referring to the Wittgenstein notion of performativity.

Similar is true of the contemporary, post-modern curriculum. There are no universal rules regarding its content, directions and its main educational objective. Instead of a universal curriculum there is a number of specific ones. Art curriculum is in fact only one of the "stories" (Efland, 1992). It might emphasize this or that. The major objective of art curriculum in elementary or grammar school is - similar as Smolik notes it - a matter of agreement, consensus or majority within a certain social setting.

With regard to art curriculum, this might be many a thing. It might be about focusing on visual literacy, learning the language of art and its use. Furthermore, it might also focus on the development of creativity, the importance of understanding modern culture, the ability to read the current social and cultural settings. Also, the objective might be developing one's ecological conscience and care for human rights, in particular with regard to fostering tolerance, equal rights and equality. When we are talking about current and acute issues it is the more sensible and justified to implement them into the art curriculum.

Our research has led us to the conclusion that students of art education at the University of Maribor, that is, future art teachers, are aware of today's demands and they accept and favour contemporary approaches to teaching art at all levels of school education. Moreover, they understand the need to comprehend the current social setting and in particular the cultural setting we inhabit, as well as recognise the importance of intertwining the course content with students' daily life and interests. Also, they know that modern visual arts and in turn the contemporary art education are both based on the conceptual approach to one's own artistic expression, and that the barriers between high and popular art are senseless, all the while the culture of peace, ecological conscience and care for equality and tolerance among human kind are crucial elements of art education.

In conclusion, endeavours towards fostering a spirit of understanding, peace, tolerance, gender equality, and friendship among people of any nation, nationality or religious belief are unfortunately not merely a basic civilisational commitment but have become, due to permanent and latent wish for the spread of evil, a concrete and urgent educational objective.

\section{Literature}

BERCE-GOLOB, H. (1982). Sodobna likovna vzgoja. V: Od risanja do likovne vzgoje. (1982). Ljubljana: Slovenski šolski muzej. 
BERCE GOLOB, H. (1993). Likovna vzgoja. Načini dela pri likovni vzgoji. Ljubljana: DZS

BOUGHTON, D. (1999). Framing Art Curriculum and Assessment Policies in Diverse Cultural Settings in: BOUGHTON, D., MASON, R. (Eds.). (1999). Beyond Multicultural art education: Internal Perspectives. (European studies in education, vol. 12). Münster; New York; München; Berlin: Waxmann. pp 331-348.

BOUGHTON, D., MASON, R. (Eds.). (1999). Beyond Multicultural art education: Internal Perspectives. (European studies in education, vol. 12). Münster; New York; München; Berlin: Waxmann.

DAWTREY, L. (Et. al.). (Eds.). (1996). Critical Studies and Modern Art. New Haven and London: Yale University Press.

EFLAND, A. (1992). Curriculum Problems at Century's End: Art Education and Postmodernism Teaching in: PIIRONEN, R. (Ed.). (1992). Power of Images. A Selection of Papers given at the European Regional Congress of InSEA Research Conference in Tampere, 6-8 Avgust, 1992. InSEA Finland and the Association of Art Teachers in Finland. pp114-121.

HARDY, T. (Ed.). (2006). Art Education in a Postmodern World: Collected Essays. Bristol, Portland: Intellect.

HERNANDEZ, F. (1999). Cultural Diversity and Art Education: The Spanish Experience; in: BOUGHTON, D., MASON, R. (Ed.). (1999). Beyond Multicultural art education: Internal Perspectives. (European studies in education, vol. 12). Münster; New York; München; Berlin: Waxmann. pp 103-114.

HICKMAN, R. (Ed.). (2005a). Critical studies in Art \& Design Education. Bristol, Portland: Intellect.

HICKMAN, R. (2005b). Why we make art and why it is taught. Bristol, UK, Portland, OR, USA: Intellect.

JAGODZINSKI, J. (1999). Thinking Through /Difference/ in Art Education Contexts: Working the Third Space and Beyond; in: BOUGHTON, D., MASON, R. (Eds.). Beyond Multicultural art education: Internal Perspectives. (European studies in education, vol. 12). Münster; New York; München; Berlin: Waxmann. pp 303-330.

KREK, J. (Ed.). (1995). Bela knjiga o vzgoji in izobraževanju v Republiki Sloveniji. Ljubljana: Ministrstvo za šolstvo in šport.

MANTERE, M. H. (1992). Ecology Environmental Education and Art Teaching in: PIIRONEN, R. (Ed.). (1992). Power of Images. A Selection of Papers given at the European Regional Congress of InSEA Research Conference in Tampere 6-8 Avgust 1992. InSEA Finland and the Association of Art Teachers in Finland. pp 17-28.

MASON, R. (1999). Multicultural Art Education and Global Reform; in: BOUGHTON, D, MASON, R. (Eds.). (1999). Beyond Multicultural art education: Internal Perspectives. (European studies in education, vol. 12). Münster; New York; München; Berlin: Waxmann. pp 3-20.

SMOLIK, N. (1999). Kdaj postane nek objekt umetniški objekt (Wann wird ein Objekt zum Kunst objekt? Oder, nach welchen Regeln beurteilt man die heutige Kunst). Likovne besede, 49-50, pp 94-96.

WALDRON, J. (1998). Rushdie in religija. Problemi, 36, 3-4, pp 139-145.

WINTERSTEINER, W. (2003). Postmoderna, pluralizem in pedagogika - kulturno izobraževanje v časih globalizacije (Postmodernism, Pluralism and Pedagogy - Culture Education in the Period of Globalisation). Sodobna pedagogika, 54, 3, pp 22-38.

ZUPANČIČ, T. (2006). Metoda likovnopedagoškega koncepta. Ljubljana: Zavod za šolstvo republike Slovenije. 
ZUPANČIČ, T. (2007). Methode des kunstpädagogischen Konzepts in: BUCHKÜHLE, C. P., KETTEL, J., URLAß, M. (Eds.). (2007). Horizonte. Internationale Kunstpädagogik. Oberhausen: Atena Verlag. pp.175-193.

ZUPANČIČ, T. (2009). Convention on the rights of the child within the contemporary post-modern art education. In: Neue Architekturen im europäischen Hochschulraum: Konferenzband, Wien, 7. und 8. Mai 2009, (Europäische Identität, Bd. 3). Wien. pp 171-177.

ZUPANČIČ, T. (2011). Prepovedane teme v sodobni umetnostni vzgoji. Revija za elementarno izobraževanje. 4, 1-2. str. 47-60.

ŽIŽEK, S. (1997a). Kuga fantazem. Ljubljana: Društvo za teoretsko psihoanalizo.

ŽIŽEK, S. (1997b). The Plague of Fantasies, New York: Verso

Metodički obzori 7(2012)2

Izvorni znanstveni rad

UDK: 378.637(497.4Maribor):75

Primljeno: 13. 1. 2011.

\title{
STAVOVI STUDENATA LIKOVNE UMJETNOSTI SVEUČILIŠTA U MARIBORU PREMA USMJERENJIMA I SADRŽAJIMA SUVREMENOG LIKOVNOG OBRAZOVANJA
}

\author{
Tomaž Zupančič, PhD, assistant prof. \\ Faculty of Education \\ University of Maribor (Slovenia) \\ e-mail: tomaz.zupancic@uni-mb.si
}

$S \boldsymbol{a} \check{z} \boldsymbol{e} \boldsymbol{t} \boldsymbol{a} \boldsymbol{k}$

Rad predstavlja neke od sadržaja suvremenog likovnog obrazovanja inkorporiranih u program likovne pedagogije na Sveučilišta u Mariboru. Ovi sadržaji proizlaze iz postmodernog likovnog kurikuluma. Jedan od najznačajnijih zadataka suvremene likovne edukacije postmodernog doba je osposobljavanje mladih ljudi za razumijevanje kulture u kojoj žive. Suvremena likovna edukacija ima uporište u globalnim temeljima. Naglašava koncepte sukladno postmodernoj paradigmi i ruši prepreke između visoke i popularne umjetnosti. Interkulturalna je i multikulturalna te razvija aspekte mirovne kulture.

Ukoliko razvijanje kreativnih potencijala, likovno-vizualno opismenjavanje te razumijevanje suvremenog kulturnog svijeta ostaju prioriteti likovnog odgoja, tada, sukladno modernom dobu treba dodati sljedeće: razvoj ekološke svijesti i brigu za ljudska prava, osobito u smislu isticanja tolerancije i jednakosti. Empirijski dio rada predstavlja upitnik za studente i njihove stavove. Studenti su rangirali sadržaje prema značajnosti i upotrebljivosti u njihovoj budučoj učiteljskoj praksi. Naglasili su značajnost i potrebu po inkorporiranju suvremenih sadržaja v današnju likovno pedagošku praksu.

Ključne riječi: Likovni odgoj, postmodernizam, suvremena umjetnost, ekologija, mir, tolerantnost 